\title{
Correlations between maternal and neonatal serum selenium levels in full term neonates with hypoxic ischemic encephalopathy
}

\author{
Abdel-Azeem M. El-Mazary ${ }^{1 *}$, Reem A. Abdel- Aziz ${ }^{1}$, Ramadan A. Mahmoud², Mostafa A. El-Said ${ }^{3}$ \\ and Nashwa R. Mohammed ${ }^{1}$
}

\begin{abstract}
Perinatal hypoxic-ischemic encephalopathy (HIE) is an important cause of brain injury in the newborn and can result devastating consequences. The principle mechanisms underlying neurological damage in HIE resulting from hypoxemia and/or ischemia is deprivation of glucose and oxygen supply which energy failure. A consequent reperfusion injury often deteriorates the brain metabolism by increasing the oxidative stress damage. Selenium is a constituent of the antioxidant enzyme Glutathione peroxidase and is vital to antioxidant defense. This study aimed to measure the serum selenium levels in full term neonates with HIE and their mothers and to correlate between them and the severity of HIE.
\end{abstract}

Methods: The study included 60 full term neonates with HIE admitted to NICU of Minia university hospital during the period from January 2014 to February 2015. Twenty apparently healthy full term neonates selected as a control group. After history taking and careful clinical examination; all neonates were subjected to: Complete blood count, renal and liver function tests and serum electrolytes. Serum selenium was measured for all neonates and their mothers within $48 \mathrm{~h}$ of life using atomic flame spectrophotometer method.

Results: Neonates with HIE had significant lower serum selenium levels than normal healthy neonates $\left(p=0.001^{* *}\right)$ with the lowest levels in neonates with severe HIE but there were no significant differences between patients and controls as regards the maternal serum selenium levels. Significant negative correlations between serum selenium levels and the severity of HIE and base excess were present, while positive significant correlations were present with Apgar score and $\mathrm{pH}$. There were no correlations between serum selenium levels and maternal serum selenium levels urea or creatinine levels.

Conclusions: Neonates with HIE had lower serum selenium level than normal healthy neonates which is not dependent on the maternal serum selenium levels and was negatively correlated with the severity of HIE.

Keywords: Selenium, Neonates, Hypoxic, Ischemic, Encephalopathy

\section{Background}

Perinatal hypoxic-ischemic encephalopathy (HIE) is an important cause of brain injury in the newborn and can result in long-term devastating consequences [1]. The development of brain injury after hypoxic insult is an evolving process during the acute insult and extending into a reperfusion phase. The principle mechanism underlying neurological damage in HIE resulting from hypoxemia and/or ischemia is deprivation of glucose and

\footnotetext{
* Correspondence: abdelazeemhemed@yahoo.com

'Department of Pediatrics, Faculty of Medicine, Minia University, Minia, Egypt Full list of author information is available at the end of the article
}

oxygen supply which causes a primary energy failure and initiates a cascade of biochemical events leading to cell dysfunction and ultimately to cell death [2]. A consequent reperfusion injury often deteriorates the brain metabolism by increasing the oxidative stress damage with particular increase in extracellular glutamate, excessive activation of glutamate receptors (excitotoxicity), increase in cytosolic calcium $\left(\mathrm{Ca}^{2+}\right)$ and generation of oxygen free radicals. Hypothermia is the treatment of choice in neonatal HIE at present [3]. Combined therapy of hypothermia and other adjuvant neuroprotective strategies focusing on prevention of acute injuries and 
enhancement of neural repair is expected to improve the neurological outcomes of HIE [4].

Selenium is a trace element of tremendous importance in human health. It is a constituent of the antioxidant enzyme Glutathione peroxidase and therefore is vital to antioxidant defense. Several diseases of the neonates have been shown to be caused at least in part by oxygen free radicals like neuronal injury of HIE, bronchopulmonary dysplasia, retinopathy of prematurity, necrotizing enterocolitis and patent ductus arteriosus. Good selenium nutrition is important for antioxidant defense in neonates [5].

\section{Aim of the work}

This study aimed to measure the serum selenium levels in full term neonates with hypoxic ischemic encephalopathy and their mothers and to correlate between these levels and the grades of HIE according to Sarnat and Sarnat staging system.

\section{Methods}

This study included 60 full term ( $\geq 37$ weeks) neonates with HIE (group I) admitted to neonatal intensive care unit of Minia university hospital for children, gynecology \& obstetrics after approval of hospital ethics committee \& informed parents' consents, during the period from January 2014 to February 2015. According to Sarnat \& Sarnat staging system; the neonates of this group classified into 3 subgroups as follow: neonates with mild HIE (20 neonates), with moderate HIE (20 neonates) and with severe HIE (20 neonates). Twenty apparently healthy full term neonates delivered in Minia university hospital selected as a control group (group II) and matched in terms of age, weight, sex and gestational age with the study group.

The criteria for diagnosis of HIE according to American academy of pediatrics (AAP) were: Apgar score $\leq 3$ for $\geq 10 \mathrm{~min}$, disturbed conscious level, abnormal neuromuscular control in the form of (abnormal muscle tone, abnormal posture, abnormal stretch reflexes and presence or absence of segmental myoclonus), abnormalities in complex reflexes in the form of (suckling, Moro, oculovestibular and tonic neck), abnormal autonomic function (abnormal pupil size, abnormal respiration, abnormal heart rate, abnormal GIT motility) presence or absence of seizures, $\mathrm{PH} \leq 7.0$ and base deficit $\geq 16 \mathrm{mmol} / \mathrm{L}[6,7]$.

Preterm neonates less than 37 weeks, neonates with sepsis, respiratory distress, jaundice, CNS infection as well as neonates with renal, cardiovascular, hepatic diseases, associated congenital anomalies were excluded from the study. Maternal diseases as hypertension, diabetes mellitus, cardiac, neurological diseases and anemic mothers were excluded from the study. After history taking and careful clinical examination; all neonates were subjected to the following laboratory investigations:
Complete blood count (by Sysmex, Japan), urea and creatinine as well as serum electrolytes (sodium, potassium and ionized calcium) were measured (by fully automated clinical chemistry auto-analyzer system Konelab 20i), liver function tests (using Integra 400 auto analyzer). Another sample of venous blood was aspirated within the first $48 \mathrm{~h}$ of life from all neonates as well as their mothers to measure the serum selenium levels using atomic flame spectrophotometer method, hydride generation atomic absorption.

\section{Statistical analysis}

Finally, data entry and analysis were all done with IBM compatible computer using Statistical Package for Social Science (SPSS) for windows version 19. Graphics were done using Excel. Quantitative data were presented by mean and standard deviation, while qualitative data were presented by frequency distribution. Correlation, Chi Square, Spearman's test and $T$ test were done. The probability of less than 0.05 was used as a cut off point for all significant tests.

\section{Results}

Neonates with HIE had significant lower serum selenium levels $(57.28 \pm 37.20 \mathrm{ng} / \mathrm{ml})$ than normal healthy neonates $(85.9 \pm 26.80 \mathrm{ng} / \mathrm{ml})(p=0.001 * *)$ with the lowest levels in neonates with severe HIE but there were no significant differences between patients and controls as regards the maternal serum selenium levels $(110.4 \pm 17.16 \mathrm{v} 118.2 \pm$ $20.11 \mathrm{ng} / \mathrm{ml}$ respectively) Table 1 \& Fig. 1.

Neonates with HIE had lower levels of hemoglobin, platelets count, $\mathrm{pH}$, sodium and ionized calcium levels than controls, but had higher levels of base excess, urea, creatinine, ALT, AST and potassium than controls Tables 2 and 1.

As regards the demographic data, there were no significant differences between neonates with HIE and controls as regards the neonatal age, gestational age, birth weight, mode of delivery and sex but they had significant lower Apgar scores at 1 and 5 min than normal healthy neonates Table 3.

Significant negative correlations between serum selenium levels and the severity of HIE and base excess were present, while positive significant correlations were present with Apgar score, $\mathrm{pH}$, hemoglobin levels and platelets count. There were no correlations between serum selenium levels and maternal serum selenium levels, neonatal age, gestational age, weight, white cell count, urea or creatinine levels Table 4 \& Figs. 2 and 3.

\section{Discussion}

Neonatal encephalopathy is a heterogeneous syndrome characterized by symptoms of central nervous system dysfunction in newborns. Neonates with encephalopathy 
Table 1 Serum selenium levels in studied groups

\begin{tabular}{|c|c|c|c|c|}
\hline Parameters & & Patients & Controls & $P$-value \\
\hline \multirow[t]{2}{*}{ Maternal serum selenium (ng/ml) } & Range & $89.5-128$ & $92-131$ & 0.08 \\
\hline & Mean \pm SD & $110.4 \pm 17.16$ & $118.2 \pm 20.11$ & \\
\hline \multirow[t]{2}{*}{ Neonatal serum selenium (ng/ml) } & Range & $10-90$ & $60.8-105.6$ & $0.001^{\mathrm{b}}$ \\
\hline & Mean \pm SD & $57.28 \pm 37.20$ & $85.9 \pm 26.80$ & \\
\hline \multirow[t]{2}{*}{ S. selenium in mild HIE (ng/ml) } & Range & $61-90$ & $60.8-90.2$ & 0.05 \\
\hline & Mean \pm SD & $82.25 \pm 25.10$ & $85.9 \pm 26.80$ & \\
\hline \multirow[t]{2}{*}{ S. selenium in moderate HIE $(\mathrm{ng} / \mathrm{ml})$} & Range & $45-70$ & $60.8-105.6$ & $0.001^{\mathrm{b}}$ \\
\hline & Mean \pm SD & $60.50 \pm 7.200$ & $85.9 \pm 26.80$ & \\
\hline \multirow[t]{2}{*}{ S. selenium in severe HIE $(\mathrm{ng} / \mathrm{ml})$} & Range & $10-49$ & $60.8-105.6$ & $0.001^{b}$ \\
\hline & Mean \pm SD & $29.10 \pm 18.815$ & $85.9 \pm 26.80$ & \\
\hline
\end{tabular}

${ }^{a}$ significant, ${ }^{b}$ highly significant

S. serum, HIE hypoxic ischemic encephalopathy

may exhibit abnormal level of consciousness, seizures, tone and reflex abnormalities, apnea and feeding difficulties [8].

Selenium is a trace element of very importance in human health. It is a constituent of the antioxidant enzymes as Glutathione peroxidase and therefore is vital to antioxidant defense. Several diseases of the neonate have been shown to be caused by oxygen free radicals including retinopathy of prematurity, bronchopulmonary dysplasia, necrotizing enterocolitis and patent ductus arteriosus [9-11].

In this study neonates with HIE had significant lower serum selenium levels than normal healthy neonates ( $p$-value $\left.=0.001^{* * *}\right)$ and those with severe HIE were the most affected group than neonates with moderate HIE and/or mild HIE.

Selenium which is nutritionally essential for humans is a constituent of more than two dozen sialoproteins that play a critical role in CNS protection from oxidative damage as well as during stressful conditions as infection, reproduction, thyroid hormone metabolism and DNA synthesis [12-14].

In our study there were no significant differences between patients and controls as regards the neonatal age, gestational age, birth weight, sex and mode of delivery

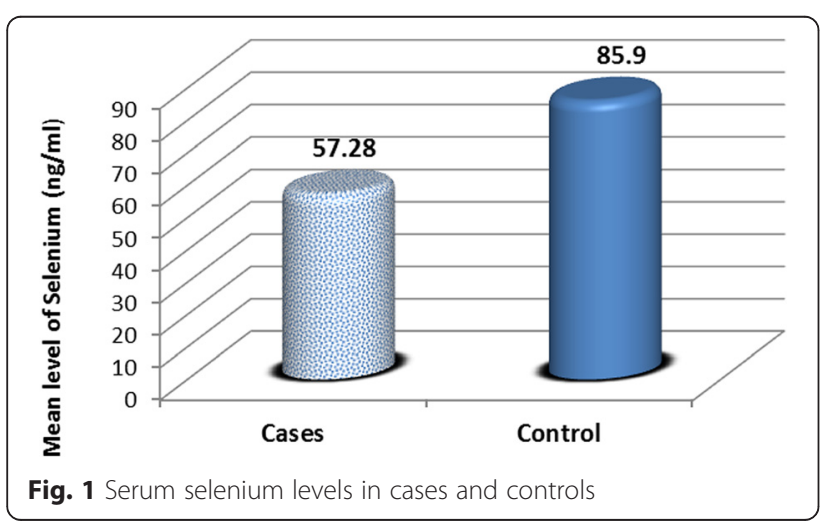

except for Apgar scores at one and five minutes which were lower in patients than controls as expected and this is agreement with American academy of pediatrics (AAP), 1996 [15].

There were no significant differences in this study between neonates with HIE and controls as regards the maternal serum selenium levels as well as there were no significant correlations between neonatal serum selenium levels and maternal serum selenium levels and this means that the lower levels of selenium in neonates with HIE were not dependent on the maternal selenium levels.

These results are in agreement with Boskabadi et al., 2010 [16] who studied the relation between maternal and neonatal selenium levels and the effect of selenium supplementation during pregnancy on neonatal oxidative stress prevention and proved that maternal selenium supplementation during pregnancy was safe but was not associated with a significant change in the extent of oxidative stress in neonates which means that maternal serum selenium levels had no effect on oxidative stress which occurs during the pathophysiology of HIE.

Geeta et al., 2000 [17] reported that maternal age, parity and socio-economic status did not affect the plasma selenium levels; the results which support ours.

Moreover, neonates with HIE had lower levels of $\mathrm{pH}$ and higher levels of base excess secondary to anaerobic glycolysis and increased production of lactic acid (lactic acidosis) and these results were in agreement with other reports $[1,2,15]$.

The suppressive effect of hypoxia and/or ischemia on the erythropoiesis as well bone marrow functions during the neonatal period was reported by many authors explaining the lower levels of hemoglobin and platelets count in neonates with HIE than healthy neonates [18].

Many endocrinal disturbances were reported secondary to hypoxia and ischemia during the neonatal period as pituitary, parathyroid and thyroid gland dysfunction 
Table 2 Laboratory data of studied groups

\begin{tabular}{|c|c|c|c|c|}
\hline \multirow[t]{2}{*}{ Lab. parameters } & & \multirow{2}{*}{$\begin{array}{l}\text { Patients } \\
N=60\end{array}$} & \multirow{2}{*}{$\begin{array}{l}\text { Controls } \\
N=20\end{array}$} & \multirow[t]{2}{*}{$P$ - value } \\
\hline & & & & \\
\hline \multirow[t]{2}{*}{$\mathrm{Hb}(\mathrm{g} / \mathrm{dl})$} & Range & $10-17$ & $13.5-18$ & $0.001^{b}$ \\
\hline & Mean \pm SD & $12.18 \pm 1.62$ & $15.67 \pm 1.36$ & \\
\hline \multirow[t]{2}{*}{ Platelets $/ \mathrm{mm}^{3}$} & Range & $100-430$ & $200-450$ & $0.01^{\mathrm{a}}$ \\
\hline & Mean \pm SD & $259 \pm 90.33$ & $332.20 \pm 64.29$ & \\
\hline \multirow[t]{2}{*}{$\mathrm{WBCs} / \mathrm{mm}^{3}$} & Range & $4.3-13$ & $4-11.6$ & 0.1 \\
\hline & Mean \pm SD & $6.71 \pm 2.16$ & $7.56 \pm 2.02$ & \\
\hline \multirow[t]{2}{*}{$\mathrm{pH}$} & Range & $6.87-7.11$ & $7.35-7.45$ & $0.001^{b}$ \\
\hline & Mean \pm SD & $7.06 \pm 0.18$ & $7.38 \pm 0.071$ & \\
\hline \multirow[t]{2}{*}{ Base deficit $(\mathrm{mmol} / \mathrm{L})$} & Range & $11-20$ & $11-15$ & $0.001^{b}$ \\
\hline & Mean \pm SD & $16.93 \pm 1.97$ & $13.10 \pm 1.252$ & \\
\hline \multirow[t]{2}{*}{ Urea(mg/dl) } & Range & $40-77$ & $20-44$ & $0.001^{\mathrm{b}}$ \\
\hline & Mean \pm SD & $54.82 \pm 7.92$ & $32.95 \pm 7.33$ & \\
\hline \multirow[t]{2}{*}{ Creatinine (mg/dl) } & Range & $0.8-2.5$ & $0.5-1.5$ & $0.001^{b}$ \\
\hline & Mean \pm SD & $1.863 \pm 0.44$ & $1.00 \pm 0.35$ & \\
\hline \multirow[t]{2}{*}{ ALT(Unit/L) } & Range & $25-89$ & $10-38$ & $0.001^{b}$ \\
\hline & Mean \pm SD & $56.25 \pm 17.05$ & $27.45 \pm 5.38$ & \\
\hline \multirow[t]{2}{*}{ AST(Unit/L) } & Range & $10-80$ & $8-43$ & $0.001^{b}$ \\
\hline & Mean \pm SD & $61.58 \pm 17.769$ & $26.0 \pm 4.96$ & \\
\hline \multirow[t]{2}{*}{$\mathrm{Na}(\mathrm{mmol} / \mathrm{L})$} & Range & $123-150$ & $135-148$ & $0.001^{b}$ \\
\hline & Mean \pm SD & $129.82 \pm 7.40$ & $139.09 \pm 2.92$ & \\
\hline \multirow[t]{2}{*}{$\mathrm{K}(\mathrm{mmol} / \mathrm{L})$} & Range & $3.8-7.9$ & $3.5-5.3$ & $0.001^{b}$ \\
\hline & Mean \pm SD & $6.82 \pm 0.63$ & $4.16 \pm 0.53$ & \\
\hline \multirow[t]{2}{*}{$\mathrm{Ca}(\mathrm{mmol} / \mathrm{L})$} & Range & $0.6-1.3$ & $1-1.3$ & $0.001^{b}$ \\
\hline & Mean \pm SD & $0.98 \pm 0.18$ & $1.17 \pm 0.10$ & \\
\hline
\end{tabular}

${ }^{\mathrm{a}}$ significan, ${ }^{\mathrm{b}}$ highly significant

$H b$ hemoglobin, WBCs white blood cells, ALT alanine transferase enzyme, AST aspartate transferase enzyme, Na sodium, $K$ potassium, Ca calcium

and this could explain the lower levels of sodium and ionized calcium in neonates with HIE in this study [18-20].

The higher levels of urea, creatinine and potassium associated with lower sodium and ionized calcium levels in neonates with HIE than controls could be explained in the light of the injurious effect of hypoxia and ischemia on the renal functions secondary to hypo-perfusion and ischemia of renal tissues resulting in tubular and cortical necrosis as reported by others $[19,21]$.

As a part of multiple organ dysfunction, the elevated liver enzymes in neonates with HIE may be attributed to the effect of hypoxia and ischemia on the liver functions and these results were in agreement with other studies [19-22].

Selenium has an antioxidant properties and it prevents cell bodies from oxidation and keeps them biologically healthy as reported by Rayman, 2000 and 2012 [23, 24]. This may explain the negative significant correlations between serum selenium levels and the severity of HIE, base excess and elevated liver enzymes as well as the positive significant correlations between selenium and $\mathrm{pH}$ and Apgar score at five minutes.

Wirth et al., 2010 [25] reported that neuronal selenoprotein expression is required for interneuron development and prevents seizures and neurodegeneration, also he reported that depletion of selenium or mutation results in exacerbation of neuronal loss and dysfunction are two mechanisms responsible for decreased activities of selenoenzymes.

Likewise, genetic inactivation of all sialoproteins in neurons leads to progressive neurodegeneration and these results support our results regarding the role of selenium in neuronal cell protection.

In this study there were no significant correlations between serum selenium levels and the levels of urea and creatinine which are two important markers for renal damage and this means the lower levels of serum selenium levels are not dependent on the renal function as an 
Table 3 Demographic data and Apgar score of studied groups

\begin{tabular}{|c|c|c|c|c|}
\hline \multirow[t]{2}{*}{ Characters } & & \multirow{2}{*}{$\begin{array}{l}\text { Patients } \\
N=60\end{array}$} & \multirow{2}{*}{$\begin{array}{l}\text { Controls } \\
N=20\end{array}$} & \multirow[t]{2}{*}{$P$ - value } \\
\hline & & & & \\
\hline \multirow[t]{2}{*}{ Neonatal age (days) } & Range & $1-7$ & $1-7$ & 0.4 \\
\hline & Mean \pm SD & $3.57 \pm 1.960$ & $3.15 \pm 2.033$ & \\
\hline \multirow[t]{2}{*}{ Gestational age (weeks) } & Range & $37-42$ & $37-42$ & 0.8 \\
\hline & Mean \pm SD & $39.08 \pm 1.418$ & $39.15 \pm 1.387$ & \\
\hline \multirow[t]{2}{*}{ Birth weight (kg) } & Range & $2.7-4.5$ & $2.9-4.3$ & 0.2 \\
\hline & Mean \pm SD & $3.245 \pm 0.1780$ & $3.195 \pm 0.1957$ & \\
\hline \multirow[t]{2}{*}{ Sex } & Male & $28(46.7 \%)$ & $8(40 \%)$ & 0.7 \\
\hline & Female & $32(53.3 \%)$ & $12(60 \%)$ & \\
\hline \multirow[t]{2}{*}{ Maternal age (years) } & Range & $19-38$ & $18-33$ & 0.7 \\
\hline & Mean \pm SD & $23.5 \pm 11.4$ & $22.4 \pm 10.8$ & \\
\hline \multirow[t]{2}{*}{ Mode of delivery } & Vaginal & $26(43.3 \%)$ & $8(40 \%)$ & 0.8 \\
\hline & $\mathrm{CS}$ & $34(56.7 \%)$ & $12(60 \%)$ & \\
\hline \multirow[t]{2}{*}{ Apgar score at $1 \mathrm{~min}$} & Range & $2-5$ & $8-10$ & $0.001^{b}$ \\
\hline & Mean \pm SD & $3.06 \pm 1.40$ & $8 \pm 0.78$ & \\
\hline \multirow[t]{2}{*}{ Apgar score at 5 min } & Range & $3-7$ & $8-10$ & $0.001^{\mathrm{b}}$ \\
\hline & Mean \pm SD & $4.15 \pm 1.51$ & $9 \pm 0.89$ & \\
\hline
\end{tabular}

${ }^{\mathrm{a}}$ significant, ${ }^{\mathrm{b}}$ highly significant

Table 4 Correlations between serum selenium levels and the studied parameters in patients group

\begin{tabular}{lll}
\hline Item & \multicolumn{2}{l}{ Serum selenium level } \\
\cline { 2 - 3 } & $\mathrm{r}$ & $\mathrm{p}$ \\
\hline Neonatal age (days) & 0.05 & 0.70 \\
Gestational age (weeks) & 0.18 & 0.1 \\
Birth weight (kg) & 0.01 & 0.90 \\
Apgar score at 5 min & 0.90 & $0.001^{\mathrm{b}}$ \\
Hb (g/dl) & 0.43 & $0.001^{\mathrm{a}}$ \\
Platelets/mm3 & 0.76 & $0.01^{\mathrm{a}}$ \\
WBCs/mm3 & -0.11 & 0.402 \\
$\mathrm{pH}$ & 0.29 & $0.04^{\mathrm{a}}$ \\
Base deficit (mmol/L) & -0.31 & $0.01^{\mathrm{a}}$ \\
Urea(mg/dl) & -0.08 & 0.49 \\
Creatinine (mg/dl) & 0.01 & 0.70 \\
ALT(Unit/ L) & -0.30 & $0.01^{\mathrm{a}}$ \\
AST(Unit/L) & -0.49 & $0.001^{\mathrm{a}}$ \\
Na (mmol/L) & -0.01 & 0.92 \\
K (mmol/L) & 0.03 & 0.78 \\
Ca (mmol/L) & 0.38 & $0.002^{\mathrm{a}}$ \\
\hline signfcat & &
\end{tabular}

a significant, bighly significant

$\mathrm{Hb}$ hemoglobin, WBCs white blood cells, $A L T$ alanine transferase enzyme, $A S T$ aspartate transferase enzyme, $\mathrm{Na}$ sodium, $\mathrm{K}$ potassium, $\mathrm{Ca}$ calcium excretory organ, i.e. the lower serum selenium levels are due to consumption of selenium and not due to increased secretion of it by kidneys.

As an integral part of the glutathione peroxidases and thioredoxin reductase selenium interacts with nutrients that affect cellular redox status. Selenium as glutathione peroxidase supports the activity of vitamin $E$ ( $\alpha$ - tocopherol) in limiting the oxidation of lipids. Further thioredoxin reductase maintains the antioxidant function of vitamin $C$ by catalyzing its regeneration from its oxidized form dehydroascorbic acid [26].

Yousuf et al., 2007 [27] and Sarada et al., 2008 [28] demonstrated that selenium supplementation ameliorates hypoxia/ischemia-induced neuronal death in vitro and in vivo and reported that selenium could prevent glutamate and hypoxia-induced cell death and selenium pretreatment reduces glutamate-induced reactive oxygen species (ROS) production and preserves mitochondrial membrane potential, preserves mitochondrial respiration and complex activities.

Saad et al., 2014 [29] reported that the values of serum zinc, selenium, and erythrocyte glutathione peroxidase are significantly lower in children with refractory epilepsy than healthy controls and these results support our results regarding the role of selenium in neuronal cell functions.

Finally, we can attribute the lower serum selenium levels in neonates with HIE than controls in the light of that selenium was used as antioxidant to protect brain cells from injury by free radicals that were released due to brain hypoxia and its levels were inversely related to 


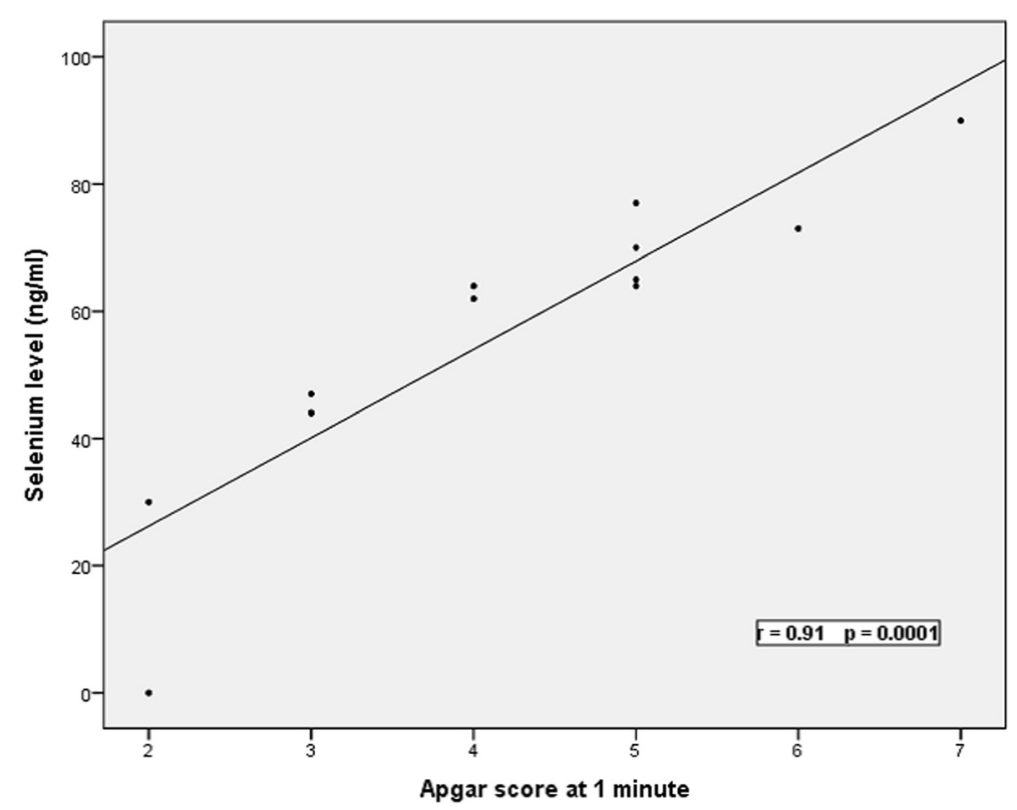

Fig. 2 Correlations between serum selenium level and Apgar score at 1 min

the degree of hypoxia and ischemia in them. The results which were in agreement with other studies reported that selenium has an important role in prognosis of hypoxic ischemic injury as it preserves mitochondrial function, stimulates mitochondrial biogenesis and reduces the infarct volume after focal cerebral ischemia [30].

Selenium significantly reduces reactive oxygen species (ROS) production in hypoxia through different complex mechanisms: the first mechanism by increasing the activity of antioxidant enzymes and protection of the mitochondrial functional performance by preserving the mitochondrial membrane potential [31,32] and the second mechanism by regulating ATP production and activities of the mitochondrial respiratory chain complexes [33,34]. Selenium-through the previous two mechanisms- inhibits the mitochondria-initiated cell

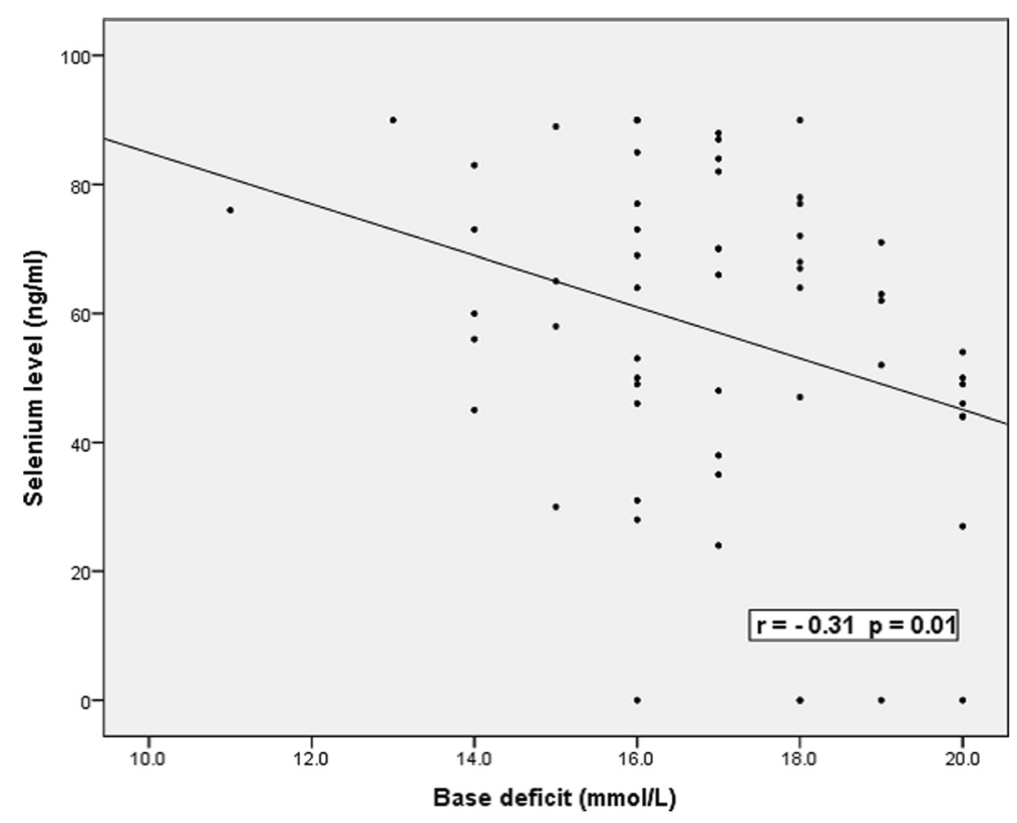

Fig. 3 Correlations between serum selenium level and base deficit 
death pathway and autophagy activation and thus improves the neuro-survival [34-36].

There were no correlations between serum selenium levels and maternal serum selenium levels, neonatal age, gestational age, weight or white cell count and this is in agreement with other studies mentioned before [34-36].

We excluded preterm neonates less than 37 weeks as well as neonates with sepsis from this study to exclude the effect of prematurity and infection on the serum selenium levels as reported by other studies [5, 14, 16, 37].

\section{Conclusion}

Neonates with HIE had lower serum selenium levels than normal healthy neonates. This decrease in serum selenium level is not dependent on their maternal selenium levels. Selenium levels were negatively correlated with the severity of HIE according to Sarnat and Sarnat staging system. Selenium supplementation for those neonates may be a helpful adjuvant line of therapy with hypothermia in the future.

\section{Competing interests}

The authors declare that they have no competing interests.

\section{Authors' contributions}

AE and RA conceived the study, carried out its designing, coordinated the implementation, helped to perform the statistical analysis and drafted the manuscript. RA and NM participated in the design of the study, analysis and interpretation of data and revised the statistics and final draft of the manuscript. RM participated in the conception and design of the study, collected the data and performed the statistical analyses. ME was responsible for interpretation of laboratory data of patients and revision of the manuscript. All authors read and approved the final manuscript.

\section{Acknowledgements}

Authors wish to thank all staff of the NICU of Minia university hospital for children and gynecology \&obstetrics for their assistance during the data collection and follow up of patients. We also wish to thank Dr. Hany Hassan Kamel, Ass. professor of gynecology \& obstetrics for his support in this work especially maternal data interpretation.

\section{Author details}

'Department of Pediatrics, Faculty of Medicine, Minia University, Minia, Egypt. ${ }^{2}$ Department of Pediatrics, Faculty of Medicine, Sohag University, Sohag, Egypt. ${ }^{3}$ Department of Clinical Pathology, Faculty of Medicine, Minia University, Minia, Egypt.

Received: 7 July 2015 Accepted: 5 October 2015

Published online: 28 October 2015

\section{References}

1. Lai M-C, Yang S-N. Perinatal hypoxic-ischemic encephalopathy. J Biomed Biotechnol. 2011;609-813.

2. Perlman JM. Summary proceedings from the neurology group on hypoxicischemic encephalopathy. Pediatrics. 2006;117(3):S28-33.

3. Higgins RD, Raju TN, Perlman J, Azzopardi DV, Blackmon LR, Clark RH, et al. Hypothermia and perinatal asphyxia: executive summary of the National Institute of Child Health and Human Development workshop. J Pediatr. 2006;148(2):170-5.

4. Volpe JJ. Neurology of the newborn. 5th ed. 2008. p. 560-85.

5. Gathwala G, Yadav OP. Selenium in the neonate. Indian J Pediatr. 2002;69(5):443-6.

6. American Academy of Pediatrics [Guideline]. Committee on fetus and newborn. Use of inhaled nitric oxide. Pediatrics. 2000;106(2 Pt 1):344-55.
7. Apgar $V$. "A proposal for a new method of evaluation of the newborn infant". Curr Res Anesth Analg. 1953;32(4):260-26.

8. Wu Y, Nordli DR, Weisman LE, Dashe JF. Clinical features, diagnosis, and treatment of neonatal encephalopathy. www.wolterskluwerhealth.com. 2014.

9. Mahan KL, Escott-Stump S. Krause's food, nutrition, \& diet therapy. 11 th ed. Philadelphia: Saunders; 2004. p. 150-4.

10. Lebovitz RM, Zhang H, Vogel H, Cartwright Jr J, Dionne L, Lu N, et al. Neurodegeneration, myocardial injury, and perinatal death in mitochondrial superoxide dismutase-deficient mice. Proc Natl Acad Sci U S A. 1996;93:9782.

11. Chawla A, Lavania AK. Oxygen toxicity. Med J Armed Forces India. 2001;57:131-3.

12. Schweizer U, Brauer AU, Kohrle J, Nitsch R, Savaskan NE. Selenium and brain function: a poorly recognized liaison. Brain Res Rev. 2004;45:164-78.

13. Schweizer U, Schomburg L, Savaskan NE. The neurobiology of selenium: lessons from transgenic mice. J Nutr. 2004;134:707-10.

14. Sunde RA. Selenium. In: Coates PM, Betz JM, Blackman MR, editors. Encyclopedia of dietary supplements. 2nd ed. London and New York: Informa Healthcare; 2010. p. 711-8.

15. American Academy of Pediatrics and Committee on obstetric practice, American College of Obstetrics and Gynecology. Committee on fetus and newborn [Guideline]: Use and abuse of the Apgar score. Pediatrics. 1996:98:141-2.

16. Boskabadi H, Rezagholizade Omran F, Tara F, Rayman MP, GhayourMobarhan M, Sahebkar A, et al. The effect of maternal selenium supplementation on pregnancy outcome and the level of oxidative stress in neonates. Natl Lib Med. 2010;12(3):254-9.

17. Geeta Gathwala MD, Yadav OP, Singh I, Sangwan K. Maternal and cord plasma selenium levels in full term neonates. Indian J Pediatr. 2000;67(10):729-31.

18. Snyder EY and Cloherty JP. Perinatal asphyxia In: Manual of neonatal care Cloherty J and Strak AR (eds): 5th ed, Lippincott- Raven, Boston 2004:536-554

19. Martin-Ancel A, Garcia-Alix A, Gaya F, Cabanas F, Burgueros M, Quero J, et al. Multiple organ involvement in perinatal asphyxia. J Pediatr. 1995;127:786-93.

20. Kurinczuk JJ, White-Koning M, Badawi N. Epidemiology of neonatal encephalopathy and hypoxic-ischaemic encephalopathy. Early Hum Dev. 2010;86(6):329-38.

21. Gupta BD, Sharma P, Bagla J, Parakh M, Soni JP. Renal failure in asphyxiated neonates. Indian Pediatr. 2005;42(9):928-34.

22. Choudhary M, Sharma D, Dabi D, Lamba M, Pandita A, Shastri S, et al. Hepatic dysfunction in asphyxiated neonates: prospective case-controlled study. Clin Med Insights Pediatr. 2015;9:1-6.

23. Rayman MP. The importance of selenium to human health. Lancet. 2000;356(9225):233-41.

24. Rayman MP. Selenium and human health. Lancet. 2012;379:1256-68.

25. Wirth EK, Conrad M, Winterer J, Wozny C, Carlson BA, Roth S, et al. Neuronal selenoprotein expression is required for interneuron development and prevents seizures and neurodegeneration. FASEB J. 2010;24:844-52.

26. Sword JT, Pope AL, Hoekstra WG. Endotoxin and lipid peroxidation in vitro in selenium- and vitamin E-deficient and -adequate rat tissues. J Nutr. 1991;121(2):258-64.

27. Yousuf S, Atif F, Ahmad M, Hoda MN, Khan MB, Ishrat T, et al. Selenium plays a modulatory role against cerebral ischemia-induced neuronal damage in rat hippocampus. Brain Res. 2007;1147:218-25.

28. Sarada SK, Himadri P, Ruma D, Sharma SK, Mrinalini PT. Selenium protects the hypoxia induced apoptosis in neuroblastoma cells through upregulation of Bcl-2. Brain Res. 2008;1209:29-39.

29. Saad K, Hammad E, Hassan AF, Badry R. Trace element, oxidant, and antioxidant enzyme values in blood of children with refractory epilepsy. Int J Neurosci. 2014;124(3):181-6.

30. Mehta SL, Kumari S, Mendelev N, Andy Li P. Selenium preserves mitochondrial function, stimulate mitochondrial biogenesis, and reduces infarct volume after focal cerebral ischemia. BMC Neuroscii. 2012;13:79.

31. Ansari MA, Ahmad AS, Ahmad M, Salim S, Yousuf S, Ishrat T, et al. Selenium protects cerebral ischemia in rat brain mitochondria. Biol Trace Elem Res. 2004;101:73-86.

32. Yeo JE, Kang SK. Selenium effectively inhibits ROS-mediated apoptotic neural precursor cell death in vitro and in vivo in traumatic brain injury. Biochim Biophys Acta. 2007;1772:1199-210. 
33. Desai VG, Casciano D, Feuers RJ, Aidoo A. Activity profile of glutathionedependent enzymes and respiratory chain complexes in rats supplemented with antioxidants and treated with carcinogens. Arch Biochem Biophys. 2001;394:255-64

34. Cui J, Holmes EH, Greene TG, Liu PK. Oxidative DNA damage precedes DNA fragmentation after experimental stroke in rat brain. FASEB J. 2000;14:955-67.

35. Scherz-Shouval R, Elazar Z. ROS, mitochondria and the regulation of autophagy. Trends Cell Biol. 2007;17:422-7.

36. Hanrahan JD, Sargentoni J, Azzopardi D, Manji K, Cowan FM, Rutherford MA, et al. Cerebral metabolism within $18 \mathrm{~h}$ of birth asphyxia: a proton magnetic resonance spectroscopy study. Pediatr Res. 1996;39:584-90.

37. Olmez A, Yalçin $S$, Yurdakök $K$, Coşkun T. Serum selenium levels in acute gastroenteritis of possible viral origin. J Trop Pediatr. 2004;50(2):78-81.

\section{Submit your next manuscript to BioMed Central and take full advantage of:}

- Convenient online submission

- Thorough peer review

- No space constraints or color figure charges

- Immediate publication on acceptance

- Inclusion in PubMed, CAS, Scopus and Google Scholar

- Research which is freely available for redistribution 